University of South Florida

DIGITAL COMMONS

Digital Commons @ University of

@ UNIVERSITY OF SOUTH FLORIDA

South Florida

1990

\title{
Variability in upwelling fields in the northwestern Indian Ocean 2. Data-model comparison at 9000 years B.P.
}

Warren L. Prell

Rebecca E. Marvil

Mark E. Luther

Florida State University, mluther@usf.edu

Follow this and additional works at: https://digitalcommons.usf.edu/msc_facpub

Part of the Life Sciences Commons

\section{Scholar Commons Citation}

Prell, Warren L.; Marvil, Rebecca E.; and Luther, Mark E., "Variability in upwelling fields in the northwestern Indian Ocean 2. Data-model comparison at 9000 years B.P." (1990). Marine Science Faculty Publications. 497.

https://digitalcommons.usf.edu/msc_facpub/497

This Article is brought to you for free and open access by the College of Marine Science at Digital Commons @ University of South Florida. It has been accepted for inclusion in Marine Science Faculty Publications by an authorized administrator of Digital Commons @ University of South Florida. For more information, please contact digitalcommons@usf.edu. 
VARIABILTTY IN UPWELLING FIELDS IN THE NORTHWESTERN INDIAN OCEAN 2. DATA-MODEL COMPARISON AT 9000 YEARS B.P.

Warren L. Prell and Rebecca E. Marvil

Department of Geological Sciences, Brown University, Providence, Rhode Island

Mark E. Luther

Florida State University, Mesoscale Air-Sea Interaction Group, Tallahassee, Florida thinner upper layer or shallower thermocline in the westernmost Arabian Sea and increased convergence, downwelling, and a thicker upper layer in the central and eastern Arabian Sea. In this experiment, the use of low resolution winds from a general circulation model (NCAR-CCM) in a highresolution ocean model seems to be appropriate for simulating the long-term averages observed in the marine sediments.

\section{INTRODUCTION}

The Arabian Sea is characterized by strong seasonal contrasts in the direction and strength of near-surface winds and in the patterns of sea surface temperature (SST). During the northern hemisphere winter, the winds are relatively weak $(2-4 \mathrm{~m} / \mathrm{s})$ and from the northeast [Hastenrath and Lamb, 1979]. A complete reversal of near-surface winds brings the high-velocity $(5-10 \mathrm{~m} / \mathrm{s})$ southwesterly summer monsoon winds and high wind stress to the western Arabian Sea [Hastenrath and Lamb, 1979; Luther and O'Brien, 1985]. The contrast between summer and winter winds is paralleled by the SST patterns of the Arabian Sea. During February, SST ranges from about $23^{\circ} \mathrm{C}$ in the northern Arabian Sea to $28^{\circ} \mathrm{C}$ closer to the equator and is characterized by isotherms that trend from east-west to northeastsouthwest. During August, the SST isotherms parallel the coastline of Arabia where the temperatures are as low as $22^{\circ} \mathrm{C}$ for individual measurements. Long term average SSTs increase from about $24^{\circ} \mathrm{C}$ in the west to about $27-28^{\circ} \mathrm{C}$ in the eastern Arabian Sea [Hastenrath and Lamb, 1979; CLIMAP Project Members, 1981]. The seasonal 
reversal of circulation causes the annual cycle of SST to be bimodal over most of the Arabian Sea - a pattern that reflects the unexpectedly low summer SST resulting from the upwelled water along the coasts of Arabia and Africa. A clear relationship exists between the strength of the southwesterly monsoon winds and the spatial distribution and magnitude of coastal SST cooling [Wyrtki, 1971; Hastenrath and Lamb, 1979; Prell and Streeter, 1982]. Direct measurements by Smith and Bottero [1977] and model results by Luther and O'Brien [1985] have shown that a continuous zone of divergence and upwelling exists in the western Arabian Sea to the north and west of the low level atmospheric Findlater Jet. Conversely, a zone of convergence and downwelling exists to the south and east of the jet. At present, the axis of the maximum surface winds trends SW-NE and is centered at about $63^{\circ} \mathrm{E}$ at $17^{\circ}$ to $18^{\circ} \mathrm{N}$ [Luther and $\mathrm{O}^{\prime} \mathrm{Brien}, 1985$ ]. If the winds increase in strength, divergence should increase in the western Arabian Sea resulting in more intense upwelling, colder waters, and a shallower thermocline. In the central and eastern Arabian Sea, convergence should increase giving greater downwelling, warmer waters, and a deeper thermocline. Hence the zonal gradient of both temperature and thermocline depth should increase with stronger winds.
Changes in past monsoonal circulation have been simulated by a series of general circulation model (GCM) experiments [Kutzbach, 1981; Kutzbach and Guetter, 1986; Kutzbach and Otto-Bleisner, 1982; Prell and Kutzbach, 1987]. Compared to modern values, model boundary conditions for the July climate at 9000 years B.P. have about $8 \%$ higher solar radiation for northern hemisphere summer. The simulations gave higher land surface temperatures, an intensified low-pressure cell over Asia, stronger low-level winds over the Arabian Sea, and increased precipitation over Africa and India. These model results are supported by reconstructions of higher lake levels [Street-Perrott and Roberts, 1983; Bryson and Swain, 1981; Ritchie et al., 1985] and the abundance of humid pollen types [van Campo, 1983; van Campo et al., 1982] in areas adjacent to the Arabian Sea. Increased monsoonal upwelling has been inferred from the plankton composition at single core sites [Prell, 1984]. These model results and data indicate that the Indian summer monsoon was more intense at 9000 years B.P. Incorporation of the stronger GCM winds (9000 year B.P. simulation) to drive a highresolution ocean model of the Arabian Sea provides a much better estimate of the oceanic upwelling response to stronger monsoonal winds. This highresolution simulation [Luther et al., this issue]
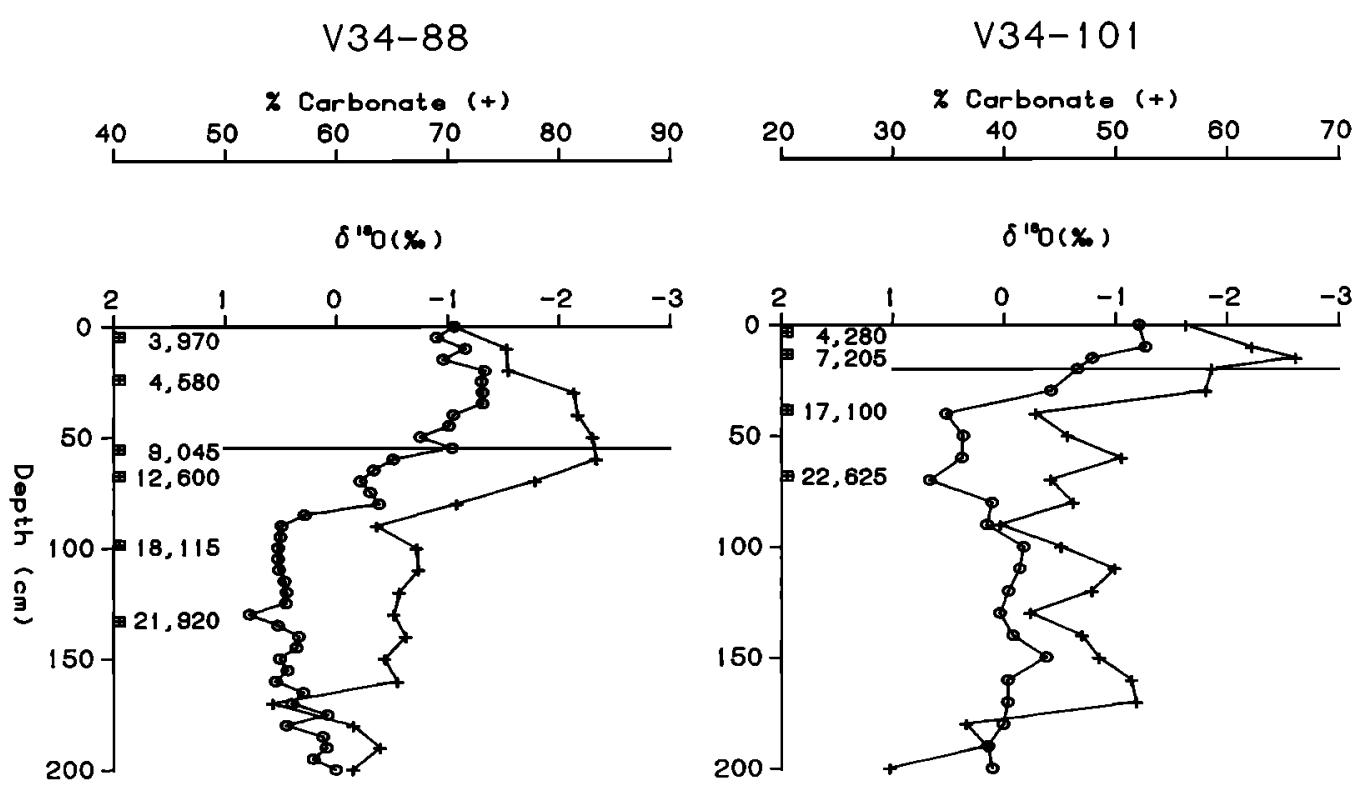

Fig. 1. Oxygen isotope stratigraphy (circles), carbonate stratigraphy (crosses), and C-14 age control for V34-88 (western Arabian Sea) and V34-101 (eastern Arabian Sea). These data along with biostratigraphic events were used to correlate cores and select the 9000 years B.P. level (shown as horizontal line). All ${ }^{14} \mathrm{C}$ ages are in jears B.P. ( ${ }^{13} \mathrm{C}$ corrected) and were measured on bulk carbonate by Krueger Geochron, Cambridge, Mass. All $\delta^{18} \mathrm{O}$ data were measured in the Benedum Stable Isotopes Lab at Brown University and carbonate data were measured in the Marine Geology Lab at Brown University. 

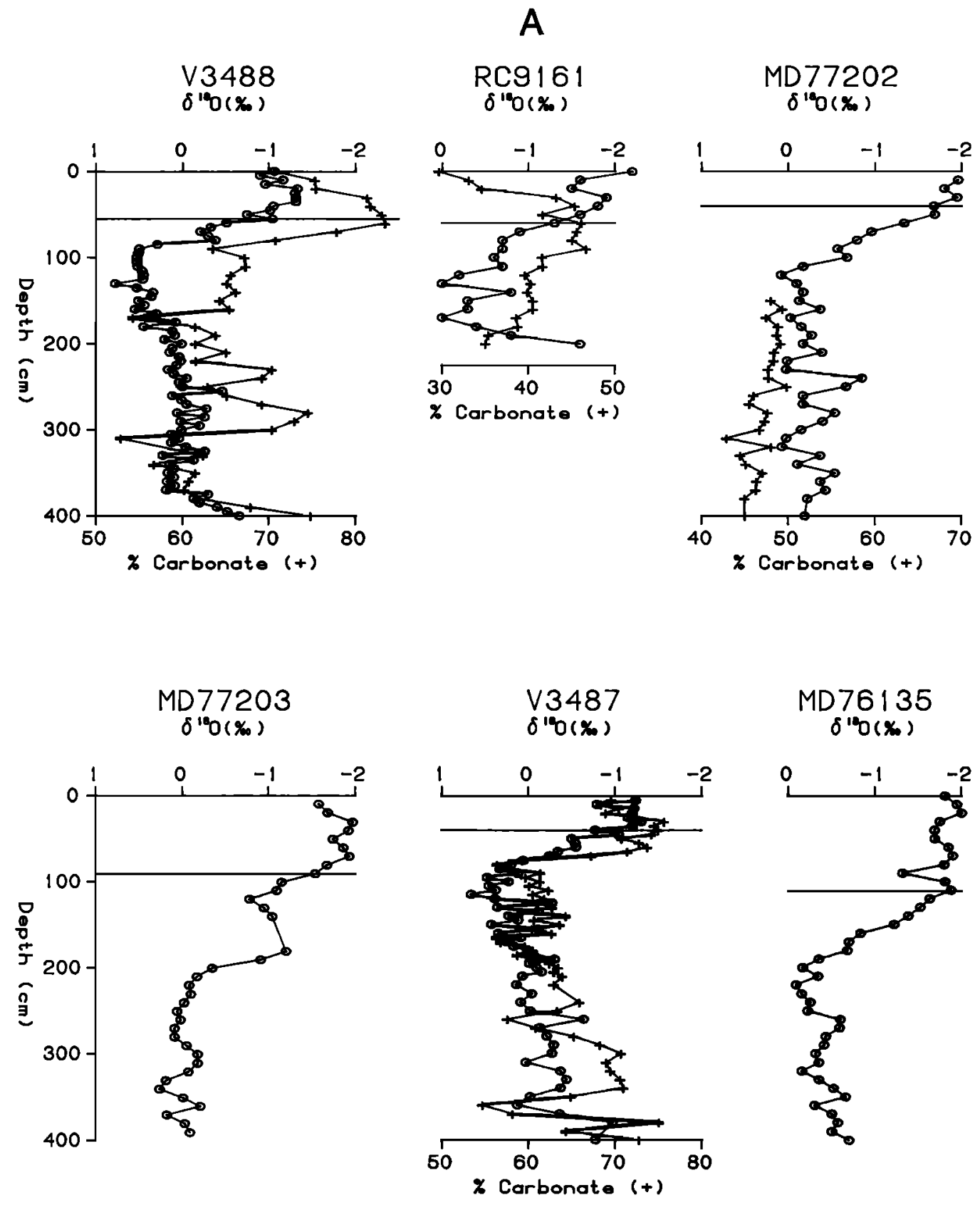

Fig. 2. Oxygen isotope (circles) and carbonate stratigraphic (crosses) control for cores in the western Arabian Sea (2A) and eastern Arabian Sea (2B). The 9000 years B.P. level is indicated by the horizontal line and its depth-in-core is given in Table 1. Data sources are given in Fig. 1.

produces a broad band of stronger upwelling and reduced upper layer thickness along Arabia. The 9000 years B.P. model simulation also gave increased downwelling and upper layer thickness to the south and east of the Findlater Jet, about 400-500 $\mathrm{km}$ offshore. To test these spatial patterns, we analyzed the planktonic foraminifer assemblages and estimated SST for the 9000 years B.P. interval in 12 deep-sea cores from the Arabian Sea.

\section{DATA AND METHODS}

We used cores with complete late Pleistocene and Holocene sections and accumulation rates greater 


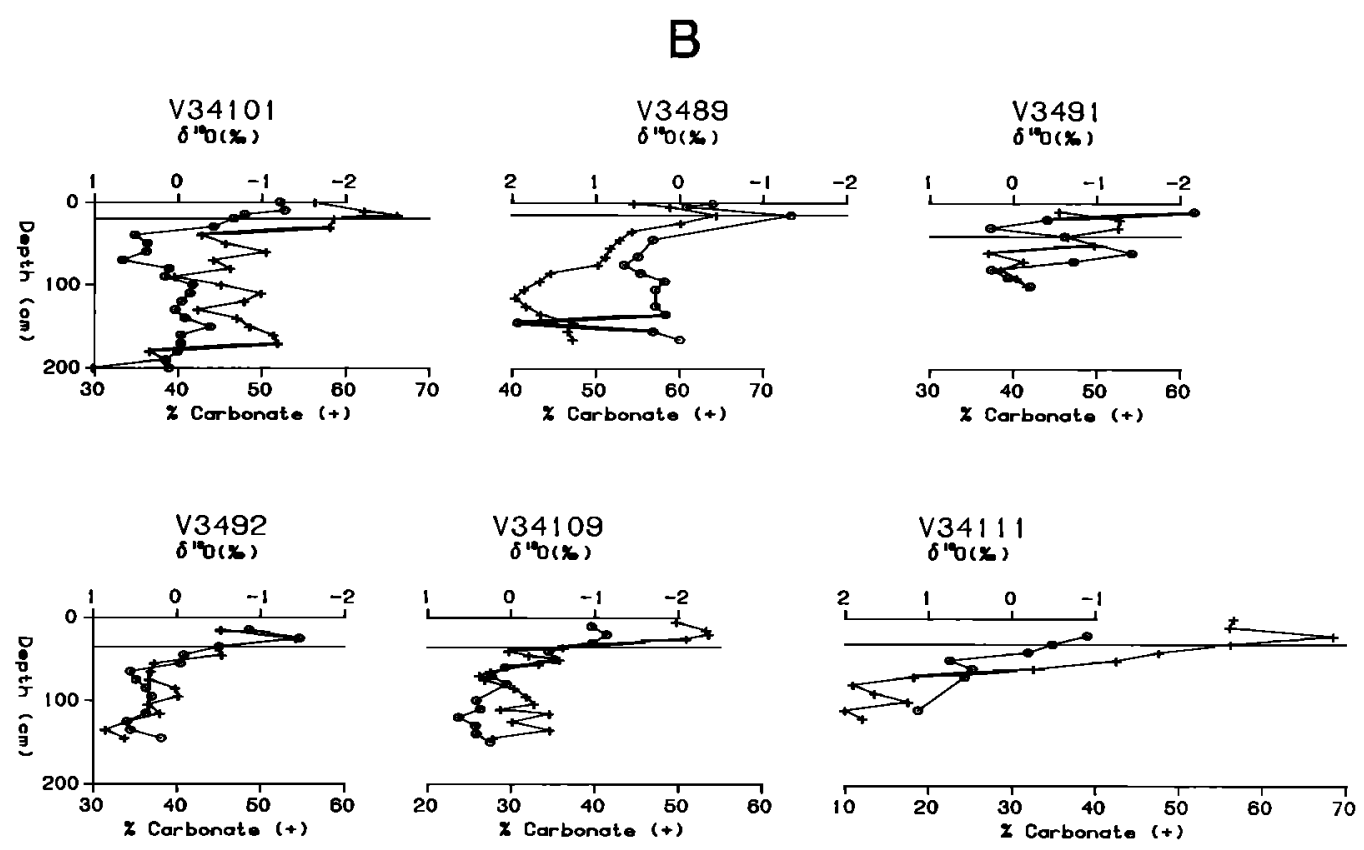

Fig. 2. (continued)

than $2 \mathrm{~cm} / 1000$ years. A stratigraphic framework for the Arabian Sea was constructed using a combination of $\delta^{18} \mathrm{O}$, carbonate, and biostratigraphy in all cores. We used ${ }^{14} \mathrm{C}$ age control in cores V34-88 and V34101 (Figure 1) to assign ages to stratigraphic events such as maxima and minima of $\delta^{18} \mathrm{O}$, carbonate content, and species abundance patterns. These stratigraphic relationships varied somewhat across the basin, so we used the chronostratigraphy of V3488 to establish age models for the cores in the upwelling region (Figure 2a) and V34-101 for the other Arabian Sea cores (Figure 2b). These data were used to identify the actual samples nearest to 9000 years B.P. in each core (Figure 2). We estimate that all samples are within about 1000 years of 9000 years B.P. Core locations and the depth-incore of the 9000 years B.P. level are given in Table 1.

Next we analyzed the planktonic foraminiferal composition of the 9000 years B.P. samples. We counted about 300 individuals in each sample and

Table 1. Core identification, map code, location, and water depth of cores

\begin{tabular}{clcccc}
\hline $\begin{array}{c}\text { Map } \\
\text { Location }\end{array}$ & Core ID & $\begin{array}{c}\text { Latitude } \\
{ }^{\circ} \mathbf{N}\end{array}$ & $\begin{array}{c}\text { Longitude } \\
{ }^{\circ} \mathbf{E}\end{array}$ & $\begin{array}{c}\text { Depth, } \\
\mathbf{m}\end{array}$ & $\begin{array}{c}\text { 9K Depth, } \\
\text { cm }\end{array}$ \\
\hline & V34-87 & $16^{\circ} 28^{\prime}$ & $59^{\circ} 45^{\prime}$ & 2144 & 40 \\
1 & V34-88 & $16^{\circ} 31^{\prime}$ & $59^{\circ} 32^{\prime}$ & 2171 & 55 \\
2 & V34-89 & $17^{\circ} 48^{\prime}$ & $61^{\circ} 52^{\prime}$ & 3760 & 15 \\
3 & V34-91 & $20^{\circ} 56^{\prime}$ & $64^{\circ} 02^{\prime}$ & 3393 & 40 \\
4 & V34-92 & $21^{\circ} 08^{\prime}$ & $65^{\circ} 07^{\prime}$ & 3166 & 35 \\
5 & V34-101 & $17^{\circ} 29^{\prime}$ & $67^{\circ} 22^{\prime}$ & 3038 & 20 \\
6 & V34-109 & $19^{\circ} 44^{\prime}$ & $66^{\circ} 05^{\prime}$ & 2742 & 35 \\
7 & V34-111 & $17^{\circ} 37^{\prime}$ & $6^{\circ} 53^{\prime}$ & 3623 & 30 \\
8 & RC9-161 & $19^{\circ} 34^{\prime}$ & $59^{\circ} 36^{\prime}$ & 3332 & 60 \\
9 & MD76-135 & $1^{\circ} 26^{\prime}$ & $50^{\circ} 31^{\prime}$ & 1895 & 111 \\
10 & MD77-202 & $1^{\circ} 13^{\prime}$ & $60^{\circ} 40^{\prime}$ & 2427 & 40 \\
11 & MD77-203 & $20^{\circ} 41^{\prime}$ & $59^{\circ} 34^{\prime}$ & 2442 & 91 \\
\hline
\end{tabular}

The depth-in-core of the 9000 year B.P. (9K). Level is given in centimeters. 
used the species-assemblage matrix of Hutson and Prell [1980] to recast the species data into assemblages. Three of their seven assemblages are important in the Arabian Sea: the "tropical," subpolar upwelling, and ecotone-Arabian Sea (here called marginal upwelling) assemblages [Hutson and Prell, 1980]. The factor loadings of these assemblages for both coretop and 9000 year B.P. samples are given in Table 2 and discussed below. Using the assemblages, we examine the difference in biogeography between the modern and 9000 years B.P. samples.

We transformed the faunal data into SST estimates, using the paleotemperature equation, FI-2, of Hutson and Prell [1980] so that our results will be compatible to those of previous studies. Application of this or any other paleotemperature equation to the Arabian Sea, is complicated by the area's complex seasonality, bimodal annual SST cycle, and its zonal SST gradients. We chose to assign temperatures so that the present sense of warm and cold seasons and seasonality was maintained. Thus in samples from the eastern Arabian Sea where values of the upwelling assemblage are less than 0.4 and the tropical assemblage dominates, the warmest estimates are assigned to the summer month of August, which is warmer than February in the modern ocean. In the upwelling region, August and February estimates are usually within $1^{\circ} \mathrm{C}$ of each other, with February SST lower, so we made no changes in the seasonal assignment of SST in the upwelling region. Comparison of modern observed SST [CLIMAP Project Members, 1981] with core top estimates (Table 3 ) are usually within $1^{\circ} \mathrm{C}$ with a slight bias for the estimated SST in the upwelling regions to be too high. We take these SSTT estimates to be an integrated response of the entire fauna that is calibrated in terms of temperature. Although the sense of relative SST change is certainly correct, the lack of samples from the core upwelling region and the combination of subpolar and Arabian Sea upwelling elements in the "upwelling" factor of Hutson and Prell [1980] raises some uncertainties about the absolute values. A summary of the observed August SST, the estimated coretop and 9000 years B.P. SST and their differences is given in Table 3.

\section{RESULTS}

The planktonic foraminiferal biogeography of the Arabian Sea is dominated by only three assemblages. The tropical assemblage is characterized by Globigerinoides ruber, and has its highest values $(>0.6)$ in the eastern and southern Arabian Sea (Figures 3 and 4 and Table 2). Most of the Arabian Sea has values between 0.4 and 0.6. At 9000 years B.P. the tropical assemblage dominates the eastern Arabian Sea, with most values exceeding 0.8 . In the western Arabian Sea values decrease slightly.

The upwelling fauna of the Arabian Sea are dominated by Globigerina bulloides, whose distribution is highly correlated with low summer SST and high nutrient concentrations in the surface waters of the Arabian Sea, both of which reflect upwelling [Prell and Curry, 1981; Prell, 1984; Cullen and Prell, 1984]. In a study of the entire Indian Ocean, this assemblage was shown to reflect both subpolar and tropical upwelling conditions [Hutson and Prell, 1980]. In core top samples, the highest values $(0.5-0.6)$ of the upwelling assemblage

Table 2. Factor Loadings of the Tropical, Upwelling, and Marginal Upwelling (Marg. Up) Assemblages for the Modern (Core Top) and 9000 year B.P. (9K) Samples

\begin{tabular}{|c|c|c|c|c|c|c|}
\hline Core ID & $\begin{array}{c}\text { Modern } \\
\text { Tropical }\end{array}$ & $\begin{array}{c}9 \mathrm{~K} \\
\text { Tropical }\end{array}$ & $\begin{array}{c}\text { Modern } \\
\text { Upwelling }\end{array}$ & $\begin{array}{c}9 \mathrm{~K} \\
\text { Upwelling }\end{array}$ & $\begin{array}{c}\text { Modern } \\
\text { Marg. Up. }\end{array}$ & $\begin{array}{c}9 \mathrm{~K} \\
\text { Marg. Up. }\end{array}$ \\
\hline V34-87 & 0.44 & 0.45 & 0.59 & 0.75 & 0.60 & 0.43 \\
\hline V34-88 & 0.47 & 0.41 & 0.60 & 0.76 & 0.59 & 0.45 \\
\hline V34-89 & 0.48 & 0.42 & 0.53 & $0.36^{*}$ & 0.52 & 0.41 \\
\hline V34-91 & 0.53 & $0.84 *$ & 0.45 & 0.30 * & 0.57 & 0.19 \\
\hline V34-92 & 0.54 & $0.87 *$ & 0.48 & $0.23 *$ & 0.61 & 0.29 \\
\hline V34-101 & $0.60^{*}$ & $0.92 *$ & $0.13^{*}$ & $0.16^{*}$ & 0.31 & 0.28 \\
\hline V34-109 & $0.66^{*}$ & $0.88^{*}$ & $0.23^{*}$ & $0.11 *$ & 0.50 & 0.29 \\
\hline V34-111 & $0.61^{*}$ & $0.69^{*}$ & $0.03 *$ & $0.32 *$ & 0.56 & 0.55 \\
\hline RC9-161 & 0.53 & 0.35 & 0.62 & 0.82 & 0.55 & 0.38 \\
\hline MD76-135 & 0.57 & 0.55 & 0.50 & 0.66 & 0.61 & 0.46 \\
\hline MD77-202 & 0.53 & 0.42 & 0.58 & 0.73 & 0.51 & 0.38 \\
\hline MD77-203 & 0.56 & 0.30 & 0.51 & 0.88 & 0.63 & 0.22 \\
\hline
\end{tabular}

* identifies samples in which the tropical factor exceeds 0.6 (three modern samples and five 9K samples) and the upwelling factor is less than 0.4 (three modern samples but in six $9 \mathrm{~K}$ samples). 
Table 3. Summary of modern observed, estinated (core top) August SST's and their difference and estimated 9000 years B.P. (9K) SST's and their difference from observed and estimated (core top) modern SST's

\begin{tabular}{lcccccc} 
Core ID & $\begin{array}{c}\text { Modern } \\
\text { Observed }\end{array}$ & Coretop & Est - Obs & 9K Aug & 9K - Coretop 9K - Obs \\
\hline V34-87 & 24.7 & 25.3 & 0.6 & 23.9 & -1.4 & -0.8 \\
V34-88 & 24.7 & 25.4 & 0.7 & 23.5 & -1.9 & -1.2 \\
V34-89 & 25.3 & 25.2 & -0.1 & $25.3^{*}$ & 0.1 & 0.0 \\
V34-91 & 26.2 & 25.8 & -0.4 & $27.0^{*}$ & 1.2 & 0.8 \\
V34-92 & 26.4 & 26.9 & 0.5 & $27.1^{*}$ & 0.2 & 0.7 \\
V34-101 & 26.6 & $27.3^{*}$ & 0.7 & $26.9^{*}$ & -0.4 & 0.3 \\
V34-109 & 26.6 & $26.3^{*}$ & -0.3 & $27.4^{*}$ & 1.1 & 0.8 \\
V34-111 & 25.9 & $25.2^{*}$ & -0.7 & $26.3^{*}$ & 1.1 & 0.4 \\
RC9-161 & 24.0 & 24.8 & 0.8 & 21.9 & -2.9 & -2.1 \\
MD76-135 & 26.8 & 26.4 & -0.4 & 25.2 & -1.2 & -1.6 \\
MD77-202 & 24.7 & 25.8 & 1.1 & 24.0 & -1.8 & -0.7 \\
MD77-203 & 24.0 & 26.0 & 2.0 & 20.9 & -5.1 & -3.1
\end{tabular}

*All values in ${ }^{\circ} \mathrm{C}$. identifies samples that we have reversed the seasonal estimates of the original transfer function. This reversal maintains higher August SST in the eastem Arabian Sea where the tropical factor is high $(>0.6)$ and the upwelling factor is low $(<0.4)$.

occur off the coast of Arabia, and lower values $(<0.3)$ are found in the eastern Arabian Sea (Figures 3 and 4 and Table 2). At 9000 years B.P., values of the upwelling assemblage increase off Arabia (up to 0.8 ), and values of 0.7 extend farther eastward to about $61^{\circ} \mathrm{E}$. (Figures 3 and 4 ).

A third assemblage, characterized by Globigerinita glutinata, is also abundant in the western Arabian Sea. It seems to be most abundant between maxima of the upwelling and tropical assemblages [Hutson and Prell, 1980; Anderson and Prell, 1990]. The ecologic significance of this assemblage is not clear but it may be an ecotone between the upwelling and tropical assemblages [Hutson and Prell, 1980] or be associated with the margin of the upwelling zone. In the core top samples, the marginal upwelling assemblage has values of 0.31-0.63 centered in the west central part of the Arabian Sea. At 9000 years B.P., this assemblage decreases in relative abundance, with maximum values of $0.4-0.5$ centered on the Owen Ridge and the Gulf of Aden (Figure 4).

In summary, at 9000 years B.P. the upwelling assemblage increased in relative abundance in the western Arabian Sea and the tropical assemblage increased in relative abundance in the eastern Arabian Sea. The "marginal upwelling" assemblage decreased over most of the basin. Hence the faunal gradient across the Arabian Sea, from upwelling to tropical areas, reflects a greater partitioning or separation of assemblages at 9000 years B.P. with a sharp transition at about $62^{\circ} \mathrm{E}$.
The maps of August SST at 9000 years B.P. and $\triangle$ SST map (i.e., 9000 years B.P. estimates minus core top estimates) show that SST was lower in the western Arabian Sea (Figure 5b, c) but slightly warmer in the central and eastern Arabian Sea. The $\triangle S S T$ map (Figure 5c), shows that the zero departure contour coincides with the distribution of the upwelling assemblage values of about 0.4 at both 9000 years B.P. and today, indicating that the eastern boundary of the cool upwelled water did not migrate much farther east at 9000 years B.P. However, west of this boundary, the Arabian Sea temperatures are lower by $2^{\circ} \mathrm{C}$ or more and the upwelling assemblage is more abundant. Hence, the temperature gradient across the Arabian Sea in August is greater at 9000 years B.P. (about $6^{\circ} \mathrm{C}$ compared to $4^{\circ} \mathrm{C}$ today) similar to the faunal gradient. Estimates of February SST and $\Delta S S T$ show that most of the Arabian Sea had lower SST at 9000 years B.P. than present, possibly indicating a stronger winter monsoon circulation also.

\section{DISCUSSION AND DATA MODEL COMPARISON}

We interpret the faunal patterns and estimated SST patterns to indicate a stronger monsoonal circulation in the western Arabian Sea at 9000 years B.P. The water in the present upwelling area was colder at 9000 years B.P. but did not extend into the 
eastern Arabian Sea, where August SST actually increased, causing a sharper SST gradient across the Arabian Sea. These observations are consistent with the ocean response expected from increased southwesterly winds. The data at 9000 years B.P. show exactly the pattern predicted from the work of Luther and O'Brien [1985] and now shown in the detailed ocean model simulations of 9000 years B.P. [Luther et al., this issue]. Although our 9000 years B.P. samples have limited distribution, they show the correct sense of change compared to the model estimates of upper layer thickness [Luther et al., this issue, Figure 4] and integrated upward displacement of the layer interface [Luther et al., this issue, Figure 5] for the 9000 years B.P. situation.

First, the faunal assemblages, the SST estimates, and model results show increased zonal or offshore gradients of upwelling-downwelling. The western samples that have increased abundance of the upwelling assemblage and lower SST coincide with areas of shallow thermoclines and high integrated upward motion in the model results (Figure 6). Likewise, the areas of deeper thermocline and lower upwelling in the model coincide with the increased

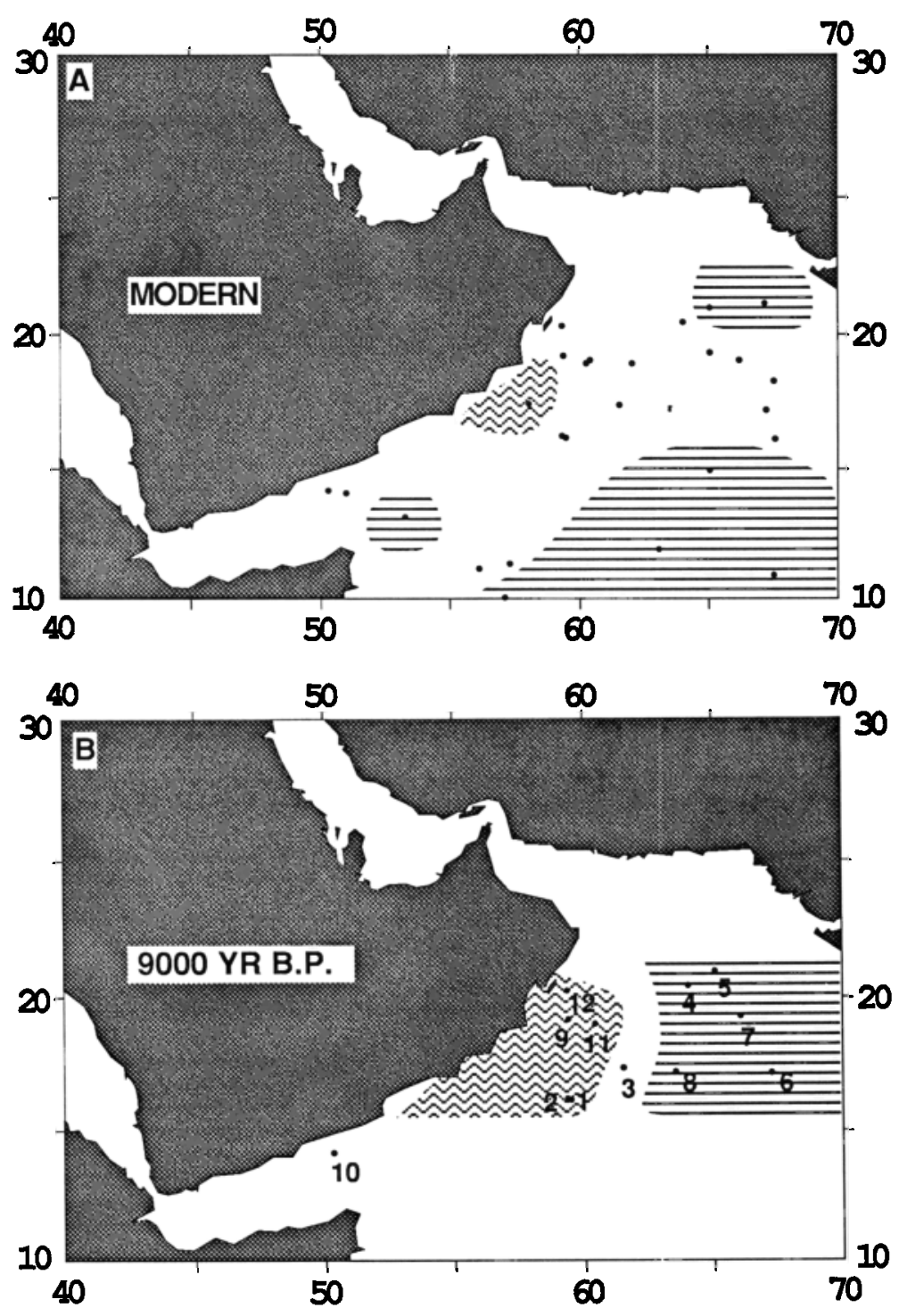

Fig. 3. The distribution of the maximum values of upwelling (wavy lines) and tropical (straight lines) assemblages for the modern (core top) (3A) and 9000 years B.P. (3B) samples. The areas indicated have factor loadings greater than 0.6 (see Table 2). Note that both assemblages expand their area of maximum values at 9000 years B.P. The numbers in the 9000 years B.P. map (3B) give the core identification (see Table 1). 

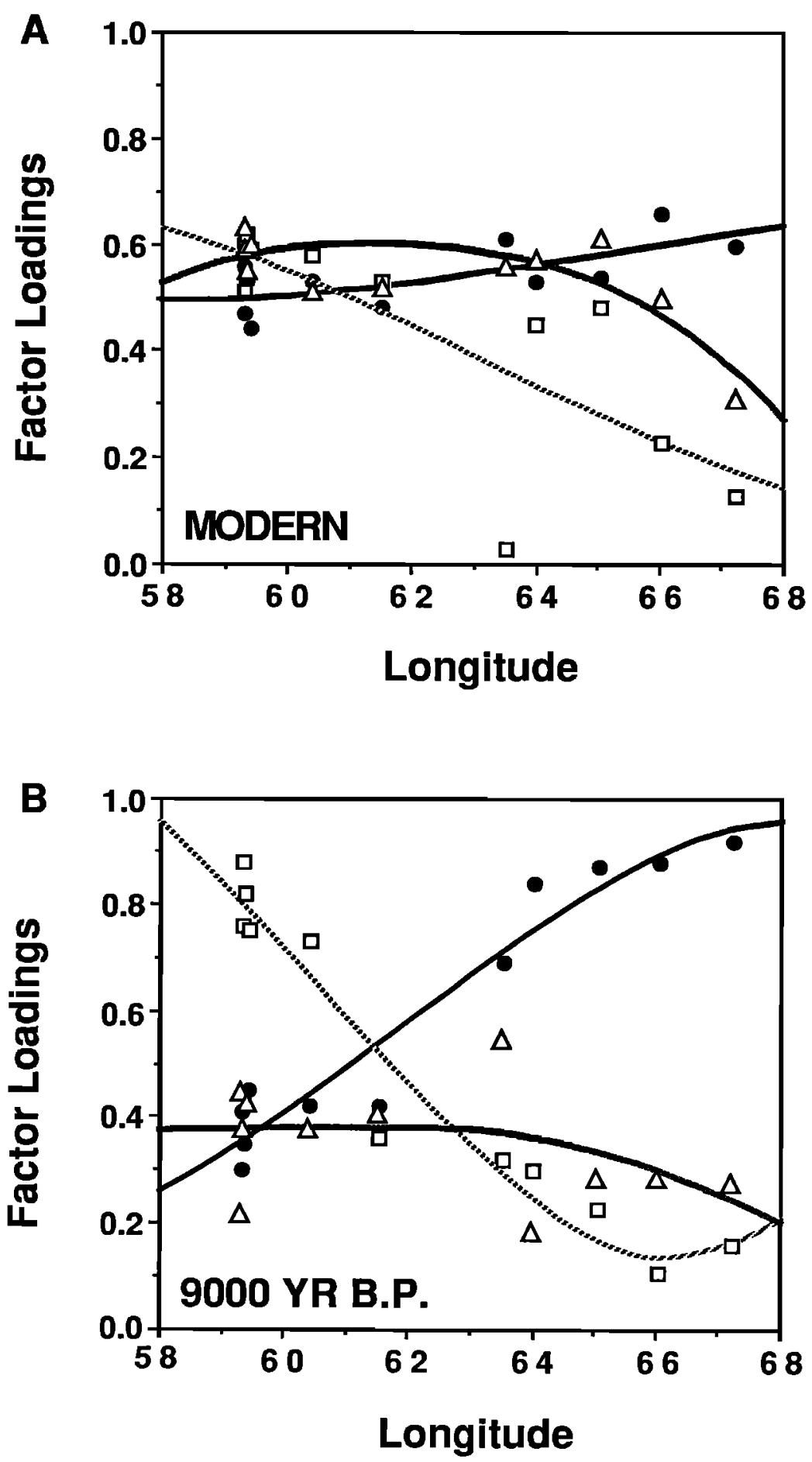

Fig. 4. Factor loading for the tropical (solid circles), upwelling (open squares), and marginal upwelling (open triangles) assemblages versus longitude for both the modern (4A) and 9000 years B.P. (4B) Arabian Sea. Data include all cores from Tables 1 and 2 except MD76-135, which is in the Gulf of Aden. Trends are drawn through the data by visual inspection. Note that at 9000 years B.P., both upwelling and tropical factors become more dominant in the western and eastern Arabian Sea, respectively. 

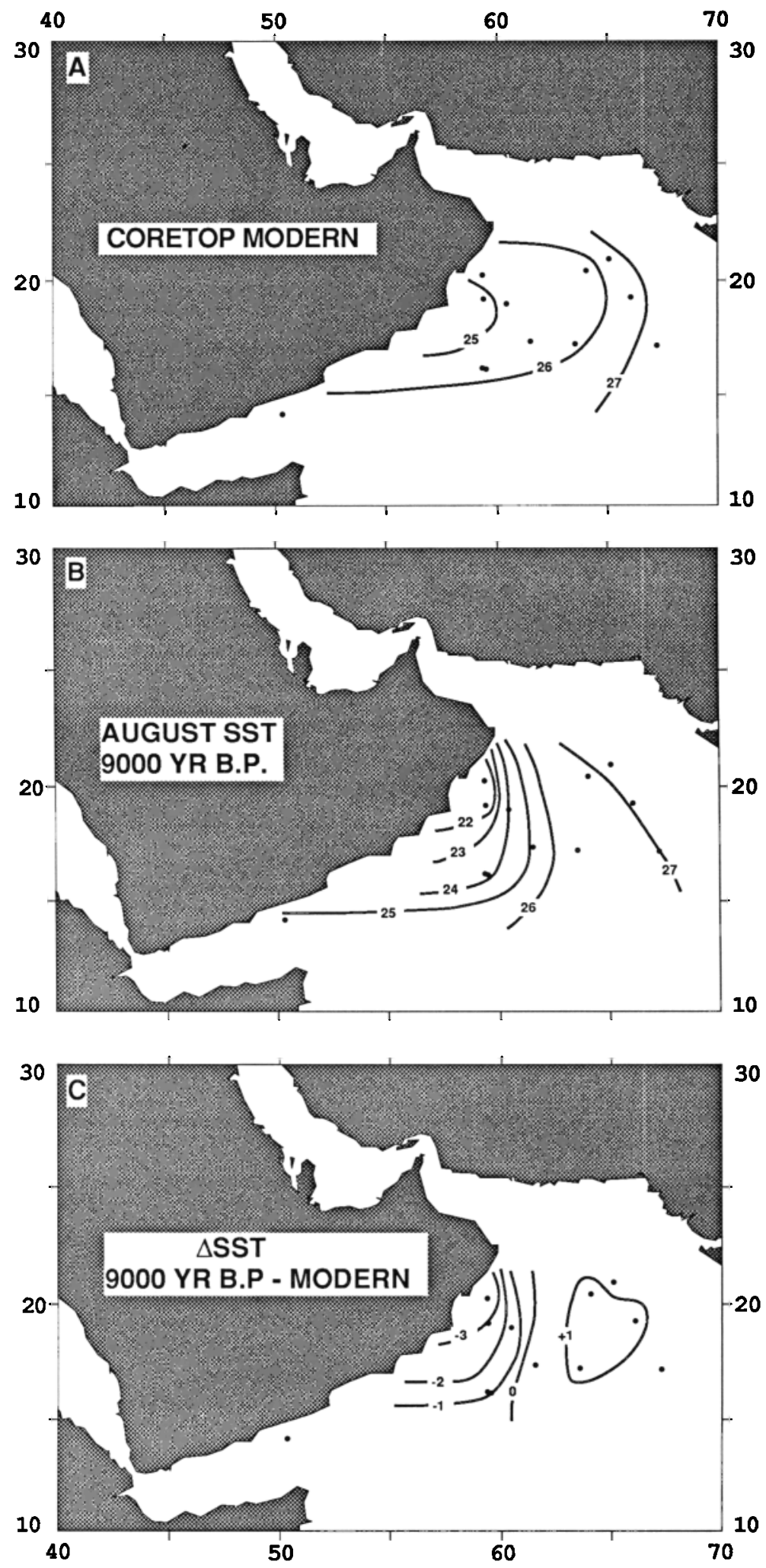

Fig. 5. The distribution of sea surface temperature (SST) for August in the modern (core top) samples (5A), estimated SST for the 9000 years B.P. samples (5B), and the difference between 9000 years B.P. SST and modern SST (5C). Note that the transition between colder and warmer SST changes lies about $60^{\circ}$ East near the present location of the Findlater Jet. 


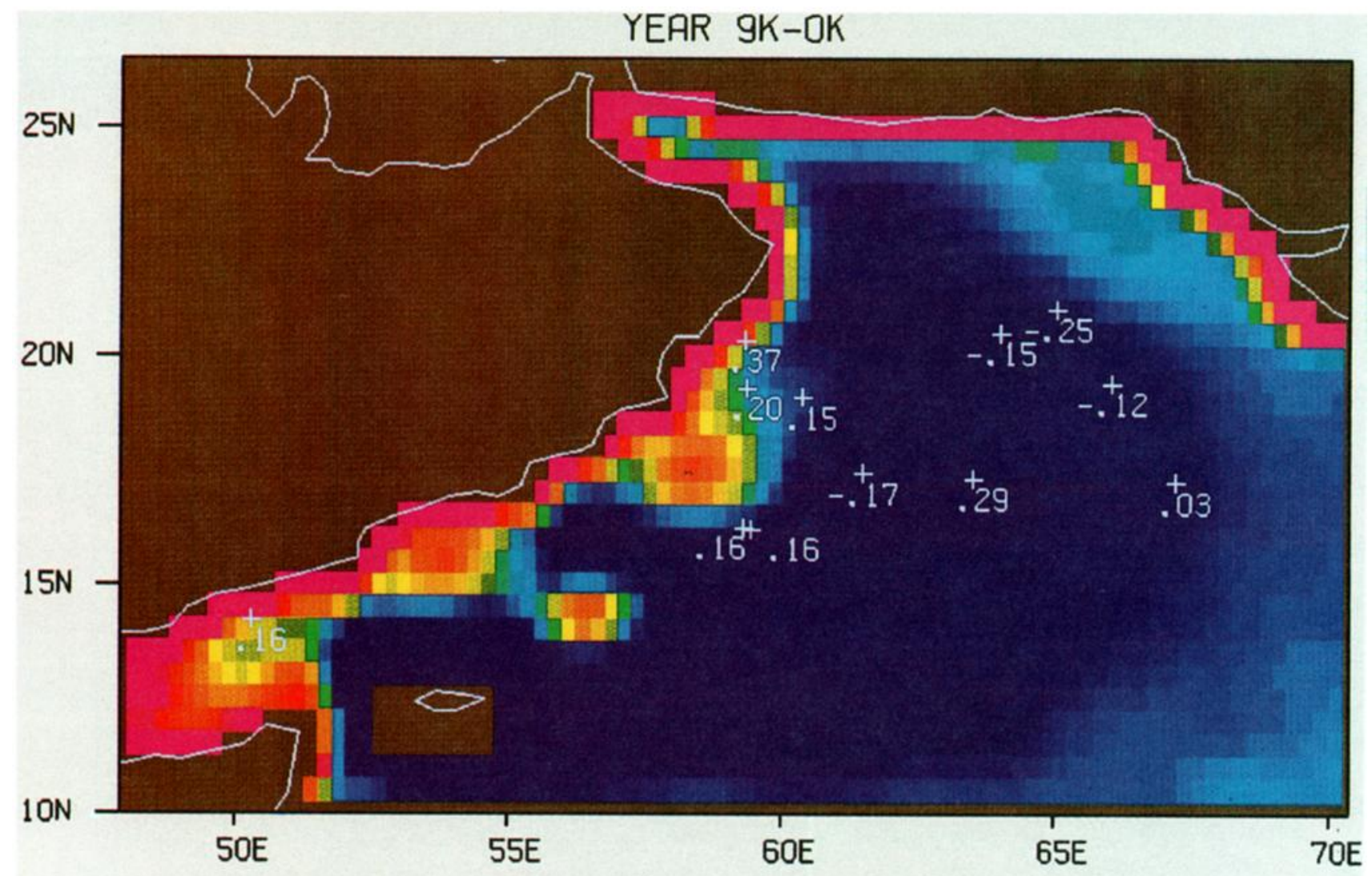

(METERS)

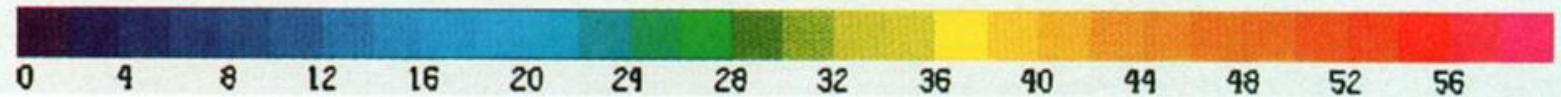

Fig. 6. Comparison of model upwelling (upward interface displacement over the upwelling season from Luther et al., this volume) and increases/decreases in the upwelling assemblage. Crosses mark the sample locations. Note that the upwelling assemblage increases west of about $60^{\circ} \mathrm{E}$ where the model upwelling is greatest. The upwelling assemblage decreases or shows little change in the eastern Arabian Sea where little to no model upwelling occurs.

abundance of the tropical assemblage and higher SST in the central and eastern Arabian Sea (Figure 6).

Second, the maximum gradient of layer thickness and upwelling, which marks the location of the Findlater Jet axis and the boundary between divergence and convergence in the upper layers of the ocean, coincides with the transition zone between the upwelling and tropical assemblages (Figures 4, $5,6)$. This coincidence implies that the location of the Findlater Jet was not appreciably different at 9000 years B.P.

The general correspondence of the 9000 years B.P. reconstruction and the model results raises some interesting implications for the use and interpretation of wind fields in paleo experiments. The spatial scale of the GCM winds $\left(4^{\circ} \times 7.5^{\circ}\right)$ is much broader than the observed winds used in the high-resolution ocean model. We interpret the relatively good fit of the seafloor faunal and SST patterns and the model results to indicate that the broad-scale GCM winds are analogous to integrating many interannual variations of the monsoon wind field. Since the sediment samples may represent several hundred years, the use of broad scale wind fields to simulate paleoceanographic patterns may be more appropriate than use of high-resolution, single year patterns. We were somewhat surprised to find that the GCM winds did create strong gradients of upwelling in the correct locations. The results of this 9000 years B.P. experiment give us confidence that the strategy of using GCM wind fields in higher resolution ocean models can be an effective tool for quantifying and interpreting the relative importance of different processes in past oceans. 
Acknowledgments. We thank Tom Crowley for organizing this symposium on paleo-ocean modeling and John Kutzbach for providing the wind fields from his GCM simulations. We also thank Andrew McIntyre and James Cullen for critical comments and suggestions on the manuscript. This research was funded by grants from the National Science Foundation (ATM-8213296 and OCE-8511571) and the Department of Energy (DEFG02-85ER60304) to Warren Prell and by grants from the Office of Naval Research, the National Science Foundation, and the Naval Ocean Research and Development Activity to James O'Brien and Mark Luther.

\section{REFERENCES}

Anderson, D. M., and W. L. Prell, High resolution record of monsoon upwelling from the proximal upwelling zone, Site 723, in Proceedings of ODP, Scientific Results, vol. 117, edited by W. L. Prell and N. Niitsuma, Ocean Drilling Program, College Station, Tex., in press, 1990.

Bryson, R. A., and A. M. Swain, Holocene variations of monsoon rainfall in Rajasthan, Quat. Res., 16, 135-145, 1981.

CLIMAP Project Members, Seasonal reconstruction of the Earth's surface at the last glacial minimum, Geol. Soc. Am. Map Chart Ser., 36, 1981.

Cullen, J. L., and W. L. Prell, Planktonic foraminifera of the northern Indian Ocean: Distribution and preservation in surface sediments, Mar. Micropaleontol., 9, 1-52, 1984.

Hastenrath, S., and P. J. Lamb, Climatic Atlas of the Indian Ocean, University Wisconsin Press, Madison, 1979.

Hutson, W. H., and W. L. Prell, A paleoecological transfer function, FI-2, for Indian Ocean planktonic foraminifera, $\mathrm{J}$. Paleontol, $, 54,381$ 399, 1980.

Kutzbach, J. E., Monsoon climate of the early Holocene: Climate experiment with the Earth's orbital parameters for 9000 years ago, Science, 214, 59-61, 1981.

Kutzbach, J. E., and P. J. Guetter, The influence of changing orbital parameters and surface boundary conditions on climate simulations for the past 18,000 years, J. Atmos. Sci., 43, 1726-1759, 1986.

Kutzbach, J. E., and B. L. Otto-Bleisner, The sensitivity of the African-Asian monsoon climate to orbital parameter changes for 9000 years BP in a low-resolution general circulation model, $\underline{\mathrm{J}}$. Atmos. Sci., 39(6), 1177-1188, 1982.

Luther, M. E., and J. J. O'Brien, A model of the seasonal circulation in the Arabian Sea forced by observed winds, Prog. Oceanogr., 1985.

Luther, M. E., J. J. O'Brien, and W. L. Prell, Variability in upwelling fields in the northwestern
Indian Ocean, 1, Model experiments for the past 18,000 Years, Paleoceanography, this issue.

Prell, W. L., Variation of monsoonal upwelling: A response to changing solar radiation, Climatic Processes and Climate Sensitivity, Geophys. Monogr. Ser., vol. 29, edited by J. E. Hansen and T. Takahashi, pp. 48-57, Washington, D.C., 1984.

Prell, W. L., and W. B. Curry, Faunal and isotopic indices of monsoonal upwelling: Western Arabian sea, Oceanol. Acta, 4(1), 91-98, 1981.

Prell, W. L., and J. E. Kutzbach, Monsoon variability over the past 150,000 years, $\mathbf{L}$ Geophys. Res., 22, 8411-8425, 1987.

Prell, W. L., and H. F. Streeter, Temporal and spatial patterns of monsoonal upwelling along Arabia: A modern analogue for the interpretation of Quaternary SST anomalies, J. Mar. Res., 40, 143-155, 1982.

Ritchie, J. C., C. H. Eyles, and C. V. Haynes, Sediment and pollen evidence for an early to midHolocene humid period in the eastern Sahara, Nature, 314(6009), 352-355, 1985.

Smith, R. L., and J. S. Bottero, On upwelling in the Arabian Sea, in A voyage of Discovery, edited by M. Angel, pp. 291-304, Pergamon, New York, 1977.

Street-Perrott, F. A., and N. Roberts, Fluctuations in closed-basin lakes as an indicator of past atmospheric circulation patterns, in Variations in the Global Water Budget, edited by F. A. StreetPerrott, M. A. Beran, and R. A. S. Ratcliffe, pp. 331-345, D. Reidel, Hingham, Mass., 1983.

van Campo, E., Paleoclimatologie des bordures de la mer d'arabie depuis 150,000 ans. analyse pollinique et stratgraphie isotopique, Ph.D. thesis, Acad. de Montpellier, France, 1983.

van Campo, E., J. C. Duplessy, and M. RossignolStrick, Climate conditions deduced from a 150kyr oxygen isotope-pollen record from the Arabian Sea, Nature, 296, 56-59, 1982.

Wyrtki, K., Oceanographic Atlas of the International Ocean Expedition, National Science Foundation, Washington, D.C., 1971.

M. E. Luther, Florida State University, Mesoscale Air-Sea Interaction Group, Tallahassee, FL 32306.

R. E. Marvil and W. L. Prell, Department of Geological Sciences, Brown University, Providence, RI 02912.

(Received September 1, 1989; accepted January 23, 1990.) 